\title{
Editorial: Oceanobs'19: An Ocean of Opportunity
}

\author{
Sabrina Speich ${ }^{1 *}$, Tong Lee ${ }^{2}$, Frank Muller-Karger ${ }^{3}$, Laura Lorenzoni ${ }^{4}$, Ananda Pascual ${ }^{5}$, \\ Di Jin $^{6}$, Eric Delory ${ }^{7}$, Gilles Reverdin ${ }^{8}$, John Siddorn ${ }^{9}$, Marlon R. Lewis ${ }^{10}$, Nuria Marba ${ }^{5}$, \\ Pier Luigi Buttigieg ${ }^{11}$, Sanae Chiba ${ }^{12}$, Justin Manley ${ }^{13}$, Amos Tiereyangn Kabo-Bah ${ }^{14}$, \\ Kruti Desai ${ }^{15}$ and Abby Ackerman ${ }^{15}$ \\ ${ }^{1}$ Laboratoire de Meteorologie Dynamique, UMR 8539 Ecole Polytechnique, ENS, CNRS, Paris, France, ${ }^{2}$ NASA Jet \\ Propulsion Laboratory, California Institute of Technology, Pasadena, CA, United States, ${ }^{3}$ College of Marine Science, \\ University of South Florida, St. Petersburg, FL, United States, ${ }^{4}$ NASA Headquarters, Science Mission Directorate, Earth \\ Science Division, Washington, DC, United States, ${ }^{5}$ Instituto Mediterráneo de Estudios Avanzados (CSIC-UIB), Esporles, \\ Spain, ${ }^{6}$ Marine Policy Center, Woods Hole Oceanographic Institution, Woods Hole, MA, United States, ${ }^{7}$ Oceanic Platform of \\ the Canary Islands, Telde, Spain, ${ }^{8}$ Laboratoire d'Océanographie et du Climat: Expérimentations et Approches Numériques, \\ Paris, France, ${ }^{9}$ Met Office, Exeter, United Kingdom, ${ }^{10}$ Department of Oceanography, Dalhousie University, Halifax, NS, \\ Canada, ${ }^{11}$ HGF MPG Joint Research Group for Deep-Sea Ecology and Technology, Max Planck Institute for Marine \\ Microbiology, Bremen, Germany, ${ }^{12}$ Japan Agency for Marine-Earth Science and Technology, Yokosuka, Japan, ${ }^{13}$ Just \\ Innovation, Inc., Duxbury, MA, United States, ${ }^{14}$ Department of Energy and Environmental Engineering, University of Energy \\ and Natural Resources, Sunyani, Ghana, ${ }^{15}$ Consortium for Ocean Leadership, Washington, DC, United States
}

Keywords: OceanObs'19, ocean observing, innovation, information, integration, interoperability, governance

\section{Editorial on the Research Topic}

\section{OPEN ACCESS}

Edited and reviewed by: Carlos M. Duarte,

King Abdullah University of Science and Technology, Saudi Arabia

*Correspondence: Sabrina Speich sabrina.speich@lmd.ens.fr

Specialty section:

This article was submitted to Ocean Observation,

a section of the journal Frontiers in Marine Science

Received: 23 August 2019 Accepted: 28 August 2019 Published: 06 September 2019

Citation: Speich S, Lee T, Muller-Karger $F$ Lorenzoni L, Pascual A, Jin D, Delory E, Reverdin G, Siddorn J, Lewis MR, Marba N, Buttigieg PL, Chiba S, Manley J, Kabo-Bah AT, Desai K and Ackerman A (2019) Editorial: Oceanobs'19: An Ocean of Opportunity. Front. Mar. Sci. 6:570.

doi: 10.3389/fmars.2019.00570
Oceanobs'19: An Ocean of Opportunity

\section{BRIEF HISTORY OF THE OCEANOBS DECADAL CONFERENCE SERIES}

The OceanObs conferences are held once every 10 years for the scientific, technical, and operational communities involved in the planning, implementation, and use of ocean observing systems. They serve to communicate progress, promote plans, and to define advances in ocean observing in response to societies' needs. Each conference provides a forum for the community to review the state of the ocean observing science and operations, and to define goals and plans to achieve over the next decade.

The First International Conference on the Ocean Observing System for Climate (OceanObs'99, Saint Raphaël, France, 17-22 Oct 1999) was jointly convened by the Ocean Observations Panel for Climate (OOPC) and the World Climate Research Program's Climate Variability and Predictability Programme (CLIVAR) Upper Ocean Panel (UOP). The main objective was to define the operational measurements needed by several related programs, specifically CLIVAR, the Global Ocean Observing System (GOOS), and the Global Climate Observing System (GCOS). OceanObs'99 brought together about 300 attendees. The conference addressed technical and scientific challenges of ocean observing systems, and also covered data analysis, modeling, and assimilation. This conference led to concrete actions. Most importantly, consensus was reached within the ocean observing community to establish and grow an internationally coordinated ocean observing system for global physical climate and ocean carbon. The details of this system were subsequently defined and presented in the first GCOS Implementation Plan. OceanObs' 99 also emphasized amongst other networks the need to build an international autonomous float program. This opportunity was taken up by sponsors, and the Argo system now provides critical operational data supporting 
a diverse range of services through improved short-term to seasonal weather and marine forecasting, and a better understanding of climate change, among many other benefits.

OceanObs'09 (21-25 September 2009, Venice, Italy) celebrated a decade of progress in implementing the initial ocean observing system. The conference convened over 600 scientists from 36 countries who represented diverse ocean stakeholder communities. Among the successes of this conference was a revolution in how physical and chemical oceanographers agreed to share data to better understand the global ocean. The outcomes included benefits through better weather forecasting, quantifying the change in $\mathrm{pH}$ of the global ocean, better understanding the physical and biogeochemical interactions between the ocean and the atmosphere, and heightened awareness that improvements in the tracking of biological variables are required. Many of these efforts led to major advances in understanding and projecting climate change. The conference developed the Framework for Ocean Observing (FOO; Lindstrom et al., 2012), which provided a strategy for defining and implementing physical, biogeochemical, and biological observing needs. This conference demonstrated the scientific and societal benefits of a sustained ocean observing system.

Now, the OceanObs'19 conference (16-20 September, 2019) seeks to further align the science, technology, and human capacity of ocean observing to address growing and urgent societal needs. The 140 Community White Papers collected under this Frontiers in Marine Science OceanObs'19 Research Topic summarize the perspective from all interested groups, including science, operational and commercial end-users, on the needs and aspirations for the coming decade. The aspirations span a broad set of communities, such as addressing the requirements of fisheries and ecosystem-based management practitioners, the maritime sector, national and local authorities, search and rescue, public and private sector researchers, and the public in general. An important goal is to further refine a governance framework that designates responsibility for product definition, production and timely delivery of fit-for-purpose information to serve user needs at the appropriate scales (global, basin, regional, national).

To reach these ambitious goals, the OceanObs'19 conference is focused around seven vital themes: Ecosystem Health and Biodiversity, Climate Variability and Change, Water Food and Energy Security, Pollution and Human Health, Ocean Hazards and Maritime Safety, Discovery, and Blue Economy. Two cross-cutting topics, Data and Information Systems and Observing Technologies and Networks, connect and integrate these themes. An overarching subject is Observing System Governance, which focuses all actors on adopting best practices for observing Essential Ocean Variables. It establishes communications protocols between elements of the Global Ocean Observing System. In addition, it guides activities to address gaps in our capacity to observe life in the sea. Ultimately, governance coordinates advocacy and planning for the funding needed to sustain ocean observations. Much of this coordination falls on the shoulders of the GOOS, and OceanObs'19 calls for the global community to participate and support this enormous effort.

\section{OBJECTIVE OF THE OCEANOBS'19 RESEARCH TOPIC COLLECTION}

Community White Papers have been an integral part of the OceanObs conference series. The objective of the OceanObs'19 Research Topic in Frontiers in Marine Science is to provide a forum for community recommendations to inform the outcome of OceanObs'19 conference and to guide post-conference activities. The community responded to a call for input to OceanObs'19 with an overwhelming number of concepts and ideas, by submitting 430 abstracts as proposals for white papers. These abstracts were refined and combined into 140 Community White Papers (CWPs). These papers promote international collaboration, describe the status of a truly largescale sustained ocean observing effort, and collectively help shape a vision for the future. They garner the collective knowledge of the community to evaluate and enhance the efficacy of our global and regional ocean observing networks. Each CWP addresses one or more of the seven themes described above and the two crosscutting topics, and makes recommendations on ocean observing governance. The CWPs specifically address improved connections between end users and providers of ocean observations, opportunities for integration of observing efforts and applications of information at the global and regional levels, and contribute to a vision in terms of ocean observing opportunities in the coming decade. They also identify substantial challenges that we need to overcome as a community and offer suggestions for solutions.

\section{BROADER CONTEXT}

The ocean provides essential services to our society. Ocean life and water quality are at the heart of the tourism, fisheries, and industries that provide benefits to millions of people. The ocean provides renewable energy and is major sources of oil, gas, and other minerals. By absorbing $\mathrm{CO}_{2}$ emissions from the combustion of fossil fuels and land use changes, the ocean moderates global warming.

Ocean observing systems are now essential to monitoring and forecasting changes in Earth's weather (minutes to days) and climate (decades to centuries; IPCC, 2013; Gleckler et al., 2016; Cheng et al., 2019). The public increasingly recognizes the critical importance of information about current and future ocean conditions to support diverse user needs. This includes better observations and predictions of wave, current, sea level, water quality, the abundance marine living resources, as well as improving marine, weather, and climate forecasting services. Major international weather and climate forecasting groups, including the European Centre for Medium-Range Weather Forecasts (ECMWF, 2016), the NOAA National Weather Service, and the World Meteorological Organization, have requirements for ocean information to enable a resilient and sustainable blue economy (WMO, 2019¹).

\footnotetext{
${ }^{1}$ https://en.unesco.org/news/new-agreement-bolsters-work-ocean-observationsresearch-and-services; https://public.wmo.int/en/media/news/wmo-hostsoceans-meetings
} 
Today, over $40 \%$ of the global human population lives within $200 \mathrm{~km}$ of the ocean. Intense urban and industrial development are exerting increasing pressures on the ocean, especially on marine ecosystems on which all human societies depend. Climate change, resource extraction, pollution from our activities on land and in the ocean, and habitat degradation due to other human activities threaten the sustained productivity and health of the ocean. The fundamental link between the ocean and human livelihood and health has led to a global social outcry over the irresponsible use of marine ecosystems. This, among other global challenges, has led the United Nations to formulate a set of Sustainable Development Goals (SDG's; 2030 Agenda for Sustainable Development). The 2030 Agenda recognizes the connection between the ocean and human well-being under SDG14 and many other interlinked SDG's (Visbeck et al., 2014; United Nations General Assembly, 2015). With this momentum, the first-ever UN Ocean conference (United Nations, 2017) was convened to support the implementation of the SDG's. Subsequently, the UN proclaimed a Decade of Ocean Science for Sustainable Development (2021-2030). The Decade of Ocean Science seeks to mobilize the scientific community, policymakers, business, and civil society around a program of joint research and technological innovation (UNESCO, 2017).

The outcomes of the OceanObs'19 conference represent a critical benchmark on how we address the challenge of sustainable development, and will significantly contribute to the Decade of Ocean Science. It is becoming more important than ever to integrate ocean observation and research agendas to meet societal needs (Visbeck, 2018). This opens opportunities for all nations to more actively engage in capacity development and in wise resource management. It provides opportunities for coastal and small island states to establish effective collaborations in multi-stakeholder processes to advance maritime activities, marine spatial planning, and effective ocean governance. It also helps to develop innovative strategies to adapt to climate change and to mitigate its impacts.

\section{DEMOGRAPHICS OF COMMUNITY WHITE PAPER PARTICIPATION}

The CWPs were contributed by more than 2,500 authors from over 79 countries. Figure 1 illustrates the geographic distributions of the authors. The authors represent organizations from various sectors, including governmental organizations (including civil and military), non-governmental organizations, non-profit organizations, industry, academic institutions, and private citizens. The number of authors, and the countries and sectors they represent, reflect the overwhelming interest and active involvement of the community. The community has high expectations for OceanObs'19 to shape the next decade of ocean observing.

\section{TOPICS OF THE COMMUNITY WHITE PAPERS IN THE COLLECTION}

The OceanObs'19 CWPs provide important contributions to the overall conference objectives (http://www.oceanobs19.net/ mission-and-vision/). The recommendations included in these papers contributed to the outcome of the conference by addressing the strategies and actions in four broad topics:

- Information to meet future user needs;

- Innovation to spur observing technologies, products, and user services;

- Integration to balance user and operator needs, capabilities, and knowledge worldwide;

- Interoperability to better communicate among observing systems, and to deliver products for users, following usability and other best practices across the globe.

The CWPs summarize key accomplishments in ocean observing, address gaps, and discuss the way forward. They emphasize the importance of ocean observations as the key source of information on natural hazards (e.g., harmful algae and bacteria blooms, tsunamis, storm surges, marine heatwaves, and storms and other extreme weather events), ecosystem health and biodiversity (including shifting distributions of organisms and the increased risk of extinctions), ocean pollution (including acidification, de-oxygenation, and plastics), and sea level change. They highlight the need for observations to support ecosystem-based management, marine and weather forecasting, climate predictions and projection, marine safety and navigation, decision support for climate adaptation, deep-ocean exploration, and seafloor mapping, among many other areas. The papers address observing systems of various scales, from the global ocean (e.g., Argo, GO-SHIP, Volunteer Observing Ships, and an active constellation of satellites), basin-scale (e.g., AtlantOS, Tropical Pacific Observing System 2020, Indian Ocean Observing System, Tropical Atlantic Observing System, Arctic Ocean and Southern Ocean observing systems, and a developing Deep Ocean Observing Strategy), regional scale (e.g., for boundary currents and inter-ocean exchanges), to various coastal observing systems. These issues and systems are all at the core of a developing blue economy.

Taken together, the CWPs represent a call to governmental and non-governmental organizations, industries, scientists and technologists, stewards and citizens to work together to support global ocean observing. They stress the need of furthering a coordinated development of the Global Ocean Observing System (GOOS) to ensure the delivery of information that will benefit human society over the long term.

Some of the strategies and actions the CWPs addressed included:

- Sustain the observation of Essential Ocean Variables (EOVs) for operational applications, including conservation and sustainable development, scientific research, and the assembling of climate data records;

- Reduce capability gaps, including the improvements of coverage and sampling in space and in time, measurement accuracies, and measurements of critical but under-measured observables (e.g., air-sea fluxes and ocean surface currents, ecosystem health and biodiversity in deep ocean as well as coastal areas).

- Develop cost-effective strategies and accelerate the infusion of technology to advance sensors, platforms, and networks; 


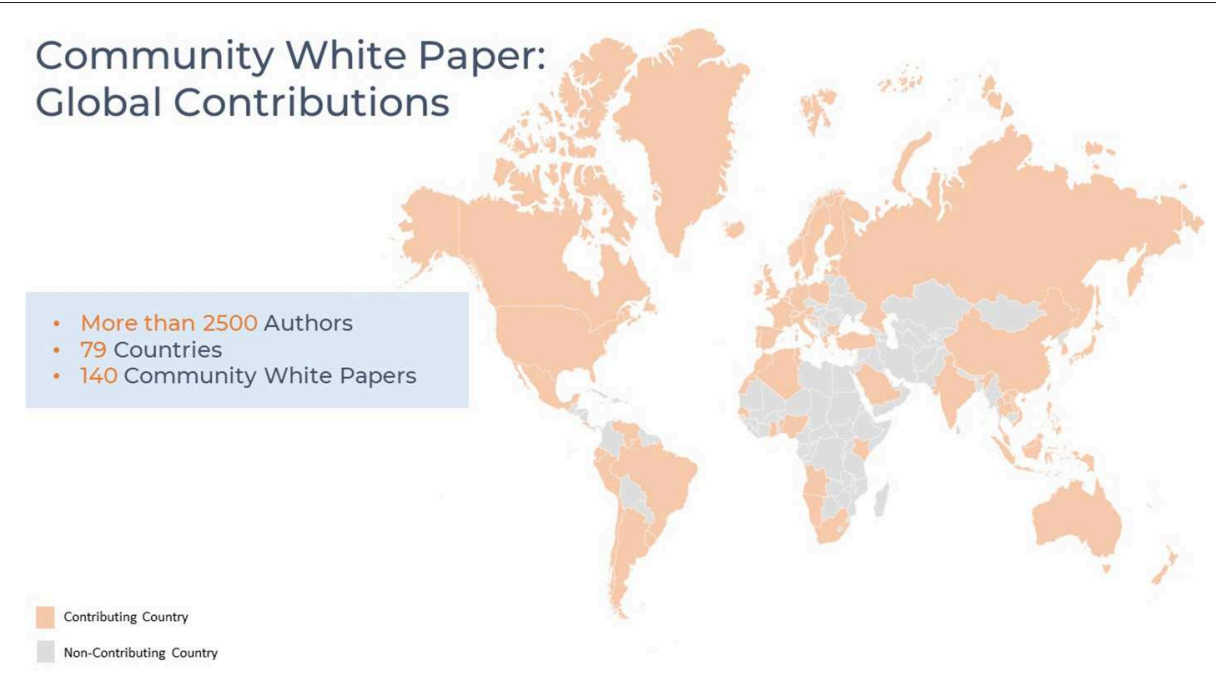

FIGURE 1 | Geographic distribution of authors contributing to the OceanObs'19 Community White Papers.

- Facilitate a governance approach that integrates observational capabilities under the framework of GOOS (e.g., Moltmann et al., 2019) across (1) different scales in space and time (global, basin-scale, regional, to coastal, and routinely, frequently, and over the long-term) (2) various platforms (in-situ, suborbital, and satellite), (3) disciplines (physical, biological, biogeochemical, and geological, and improved linkages to the social sciences), and (4) observations and forecasts (including improvements of models, assimilation, and initialization of forecasts);

- Improve the link between users and observing systems, including the private sector and bodies such as the World Meteorological Organization, the Food and Agricultural Organization, and many other government and academic entities. This includes re-enforcing the feedback loop between users and observing systems, so that system design and implementation ensure a fit-for-purpose enterprise as described in the Framework for Ocean Observing (FOO);

- Innovate data and information services to support diverse user needs across different regions and sectors, and to meet the challenges of Big Data and distributed data systems;

- Enhance and refine best practices in sensor and observing system development as well as in data and information curation and delivery, to build an international, collaborative, and multidisciplinary community of practice that jointly collects and shares global observations on EOVs for measuring change accurately and reliably;

- Strengthen capacity building and knowledge integration across the ocean observing value chain, from data collection to the generation of information and its application;

- Foster international collaborations and coordination, including free and public data access (real-time or near real-time where applicable), sharing of resources, coordination of education and outreach, and management of a shared and responsible observing system governance that provides funds for these activities.

The OceanObs'19 conference has taken the recommendations from these CPWs and many other sources and voices of the community to inform plenary presentations, panel discussion, breakout sessions, and conference posters. This input is critical for the success of the OceanObs'19 conference, and will help define the outcome of the conference and the post-conference actions. Together, the CWP and OceanObs'19 will contribute to the development of a vibrant and blue economy that comprises many sectors, that supports policies that sustain development and conservation, and shape the next decade of ocean observing.

\section{AUTHOR CONTRIBUTIONS}

SS, TL, FM-K, and LL drafted the content of this document and coordinated other author contributions. AP, DJ, ED, GR, JS, ML, NM, PB, SC, JM, and AK-B provided edits. KD and AA contributed figures and final editing.

\section{ACKNOWLEDGMENTS}

The organizers of the OceanObs'19 conference thank the authors that conceived and jointly crafted the Community White Papers for their tremendous efforts, extensive international collaborations, and community wisdom. The organizers also thank the hundreds of reviewers of the CWPs for their dedication, and the time invested in reviewing the papers. The organizers of the OceanObs'19 conference wish to thank the chief editor of the journal, Dr. Carlos Duarte, and the Frontiers Marine Science staff, for their professionalism and support in this process. 


\section{REFERENCES}

Cheng, L., Abraham, J., Hausfather, Z., and Trenberth, K. E. (2019). How fast are the oceans warming? Science 363, 128-129. doi: 10.1126/science. aav7619

ECMWF (2016). ECMWF Strategy 2016-2025: The Strength of a Common Goal. ECMWF Tech. Rep., 27. Available online at: www.ecmwf.int/sites/default/files/ ECMWF_Strategy_2016-2025.pdf

Gleckler, P. J., Durack, P. J., Stouffer, R. J., Johnson, G. C., and Forest, C. E. (2016). Industrial-era global ocean heat uptake doubles in recent decades. Nature Clim. Change 6, 394-398. doi: 10.1038/nclimate2915

IPCC (2013). Climate Change 2013: The Physical Science Basis. Contribution of Working Group I to the Fifth Assessment Report of the Intergovernmental Panel on Climate Change, eds T. F. Stocker, D. Qin, G.-K. Plattner, M. Tignor, S. K. Allen, J. Boschung, A. Nauels, Y. Xia, V. Bex, and P. M. Midgley (Cambridge; New York, NY: Cambridge University Press), 1535. doi: 10.1017/CBO9781107415324

Lindstrom, E., Gunn, J., Fischer, A., McCurdy, A., and Glover, L. (2012). A Framework for Ocean Observing: A Report by the Task Team for an Integrated Framework for Sustained Ocean Observing. Paris: UNESCO.

Moltmann, T., Turton, J., Zhang, H-M., Nolan, G., Gouldman, C., Griesbauer, L., et al. (2019). A Global Ocean Observing System (GOOS), delivered through enhanced collaboration across regions, communities, and new technologies. Front. Mar. Sci. 6:291. doi: 10.3389/fmars.2019.00291

UNESCO (2017). United Nations Decade of Ocean Science for Sustainable Development (2021-2030). UNESCO Press Release. Available online at: https:// en.unesco.org/ocean-decade
United Nations (2017). UN Ocean Conference 2017. Available online at: https:// oceanconference.un.org/

United Nations General Assembly (2015). Transforming Our World: The 2030 Agenda for Sustainable Development. A/RES/70/1 Available online at: http:// www.un.org/sustainabledevelopment/development-agenda/

Visbeck, M. (2018). Ocean science research is key for a sustainable future. Nat. Commun. 9:690. doi: 10.1038/s41467-018-03158-3

Visbeck, M., Kronfeld-Goharani, U., Neumann, B., Rickels, W., Schmidt, J., Van Doorn, E., et al. (2014). Securing blue wealth: the need for a special sustainable development goal for the ocean and coasts. Mar. Policy 48, 184-191. doi: 10.1016/j.marpol.2014.03.005

Conflict of Interest Statement: The authors declare that the research was conducted in the absence of any commercial or financial relationships that could be construed as a potential conflict of interest.

The handling editor declared past co-authorship with one of the authors NM.

Copyright (c) 2019 Speich, Lee, Muller-Karger, Lorenzoni, Pascual, Jin, Delory, Reverdin, Siddorn, Lewis, Marba, Buttigieg, Chiba, Manley, Kabo-Bah, Desai and Ackerman. This is an open-access article distributed under the terms of the Creative Commons Attribution License (CC BY). The use, distribution or reproduction in other forums is permitted, provided the original author(s) and the copyright owner(s) are credited and that the original publication in this journal is cited, in accordance with accepted academic practice. No use, distribution or reproduction is permitted which does not comply with these terms. 